\title{
WALTER BENJAMIN, UM CRÍTICO EM WEIMAR
}

Michel Amary

\begin{abstract}
RESUMO
Nosso objetivo nesse ensaio é apresentar como Walter Benjamin acompanhou as transformações de seu tempo no momento em que escrevia Origem do drama barroco alemão e como elas repercutiram e ecoaram em sua obra. Em um primeiro momento devemos localizar o despertar do interesse da histórico de nosso autor na transição do Império Guilhermino para a fundação da República. Depois, retratar os horrores da guerra pelo ethos da germanidade e pela dominação material da técnica como mistificação da histórica enquanto segunda natureza. Por fim, apresentar nos conflitos sociais durante a socialdemocracia a ascensão do nazifascismo um debate sobre soberania e estado de exceção próprios do barroco alemão. Com isso, esperamos constituir um mosaico histórico do período weimariano a partir de citações do autor oferecendo um panorama de temas que aproximam períodos históricos tão distantes.
\end{abstract}

Palavras Chaves: Walter Benjamin. Weimar. Barroco Alemão. Estado de exceção. Técnica.

\section{WALTER BENJAMIN, A CRITIC IN WEIMAR}

\begin{abstract}
Our aim in this essay is to present as Walter Benjamin followed the transformations of his time at the moment he wrote The Origin of the German Tragic Drama and how it reverberated and echoed in his work. First, we must locate the awakening of the interest of our author about history in the transition from the Guilhermino Empire to the founding of the Republic. Then, portray the horrors of war by the ethos of Germanity and the material domination of technique as mystification of the historical as second nature. Finally, to present in the social conflicts during the Social Democracy the rise of nazifascism a debate about sovereignty and state of exception, characteristic of the German baroque. With this, we hope to constitute a historical mosaic of the Weimar period from the author's quotations, offering a panorama of themes that approach such distant historical periods.
\end{abstract}

Keywords: Walter Benjamin. Weimar. German Baroque. State of Exception. Technique. 
Quando nos deparamos com Origem do drama barroco alemão (Ursprung des deutschen Trauerspiel), logo percebemos que se trata de uma obra limite do pensamento filosófico de Walter Benjamin. Concebida em 1919 como tese de livredocência para ser submetida à cadeira de História da Literatura Alemã na Universidade de Frankfurt, Benjamin foi aconselhado a retirar a sua candidatura para não sofrer a reprovação, por ele considerada humilhante. A partir daí, Benjamin desistia de sua carreira acadêmica, tomando novos rumos como intelectual independente. No entanto, o que torna esta obra um limite, não são as consequências de sua recusa para a vida do autor, tampouco ideias limitadas, e sim, que ela marca a perspectiva fronteiriça de um jovem com investigações inquietantes para a descoberta de seu amadurecimento filosófico. O seu estudo sobre o barroco é a ponte que consolida suas interpretações metafísicas e judaico-teológicas sobre a linguagem e a teoria do conhecimento para sua descoberta materialista da política e sua concepção de história. A força do texto filosófico que se encontra por detrás do discurso imbricado e da erudição das palavras, que seus pares pouco compreenderam, ganhou nova repercussão a partir de sua publicação em 1925. Quando Theodor W. Adorno, assumiu sua vaga na mesma Universidade em 1931, não deixou de apresentar em sua aula inaugural, chamada $A$ atualidade da Filosofia (Die Aktualität der Philosophie), as ideias que Benjamin expressa no seu livro do barroco. A atualidade das ideias que perpassavam o livro eram o que o tradicionalismo acadêmico não tinha vislumbrado, do Prólogo epistemológico-crítico, onde Benjamin propõe uma nova teoria do conhecimento sobre a tradição da representação que vem de Descartes e perpassa Kant, à teoria da alegoria, que visa romper com a totalidade simbólica na estética, a todo momento a obra se refere a renovação da crítica filosófica e aos acontecimentos presentes. O interesse pelo barroco alemão, um tema distante e empoeirado, vinha justamente para combater a apreensão ideológica da historiografia da arte de seu tempo, que classificava períodos históricos distintos a partir de uma grande linha histórica de formação (Bildung), mistificada como feitos nostálgicos de uma grande nação alemã. Ao mesmo tempo, Benjamin não percebia o ambiente político marcado por desgraças externas, revoltas e golpes de estado, intrigas, mortes e autoritarismos que se viu no século XVII, distantes do seu próprio contexto histórico. Nesse sentido, a obra inaugurava, apesar da abordagem do 
passado, um debate sobre a atualidade política da Alemanha e uma nova concepção de se entender a história. A imagem que Benjamin registra do período entre as duas Guerras Mundiais e a formação da República de Weimar, tem como característica principal a relação estreita entre a cultura e a política, entre a literatura e a história: "A obra de Benjamin dedica-se a precisar essas relações. Seus textos sobre poesia e vida, literatura e política, escrever e fazer pertencem aos documentos mais relevantes sobre o assunto. Essas fontes que oferecem uma visão da própria época" (BOLLE, 2000, 142). É nesse contexto que o drama barroco aparece como uma obra privilegiada. Benjamin pode acompanhar, durante a redação de sua dissertação, 0 processo histórico marcado por acontecimentos perturbadores e transformações profundas e sem precedentes na sociedade alemã desde a Primeira Grande Guerra. Assim, nosso objetivo nessa investigação é examinar a composição do ambiente político e acontecimentos históricos que marcaram a constituição do pensamento filosófico de Benjamin na elaboração do conceito de estado de exceção (Ausnahmezustand) em sua tese de livre-docência; queremos constituir uma visão histórica da época a partir dos comentários de seus próprios escritos, acompanhar as conexões do seu pensamento filosófico ancorado no processo histórico catastrófico do início do século $X X$.

\section{0 fim do Império Guilhermino: o trágico despertar para a história}

O primeiro ponto a ser abordado é o despertar da história em seu pensamento, a partir dos antecedentes político-econômicos que precederam e persistiram, influenciando na sua formação e sua condição de vida no período weimariano. Do período de unificação até o eclodir da Primeira Guerra Mundial, a Alemanha tinha passado um momento de rápida industrialização e acumulação de riquezas que viuse deteriorar em poucos anos com a fracassada campanha durante a guerra.

\footnotetext{
Entre 1870 e 1914, a Alemanha se havia transformado em um país altamente industrializado. Um pouco antes de 1870 teve início o grande desenvolvimento econômico que cuja consolidação muito contribuiu a unificação. Em seguida aumentou ainda mais a taxa de crescimento econômico, que atingiu seu ponto máximo no período entre 1890 e 1915. Todo esse desenvolvimento não teve precedentes em termos de velocidade e amplitude. A população dos Estados alemães saltou cerca de 42,5 milhões, em 1875, para aproximadamente 68 milhões, em 1915. Em 1871, mais ou
} 
menos $64 \%$ dos alemães viviam em comunidades de menos de dois mil habitantes. Esse número cresceu lentamente até 1890, mas então, caiu vertiginosamente para $40 \%$ por volta de 1910 . Neste ínterim, a proporção de alemães empregados na agricultura e no serviço florestal diminuiu de $42 \%$ em 1882, para 34\% em 1907. Fábricas e minas tomaram lugar das fazendas. Em 1882, a indústria pesada alemã empregava 356 mil operários, cerca de 1,12 milhões em 1907. Na produção do aço, em 1860 a Alemanha ficou atrás da França e muito atrás da Inglaterra. Em 1910, porém, os alemães fabricavam mais ferro-gusa e mais aço do que a Inglaterra e a França juntas. No espaço de algumas décadas, a Alemanha transformou-se de um país relativamente atrasado e predominantemente agrícola numa das maiores potências industriais do mundo (RINGER, 2000, 55)

A velocidade de industrialização que os alemães presenciaram não foi acompanhada pelo rígido e hierárquico sistema político de vocação imperial. Em cena entraram uma elite industrial que com sua força econômica competia com o poder político da aristocracia tradicional formada por funcionários públicos e profissionais liberais, e uma massa de trabalhadores operários que passaram a se unir em sindicatos e partidos. Esses atores que durante o período da guerra se aliaram em torno de um ideal nacionalista e patriótico sustentado pelo Reich, onde o "imperador não conhecia mais direita e esquerda, diziam, só haviam alemães" (KLEIN, 1995,19), inversamente modificaram o campo de força do tabuleiro político quando o testemunho do desenvolvimento econômico e industrial se tornou uma herança de crise econômica e miséria:

Os esforços da guerra haviam absorvido a tal ponto as menores atividades
que acabaram por esmagar tudo. O número de soldados havia mais que
triplicado desde 1914 , atingindo quase 10 milhões. Nas indústrias, o número
de funcionários diminuíra um quarto e das operárias cresceram $50 \%$. No
essencial, a mão-de-obra era utilizada para manutenção ou construção de
material bélico. Nas indústrias têxteis e alimentares, pelo contrário, caíra para
$60 \%$. Todo país havia se transformado, mergulhado rapidamente num
desequilíbrio econômico e social. (RICHARD, 1988,14)

Em poucos meses, quando rendida a Alemanha contava seus corpos, o rastro de miséria que a guerra deixou, começou a intensificar, aumentando o desespero e o descontentamento popular com o regime Imperial. Na dimensão econômica "a austeridade ganhara as avenidas mais elegantes da capital" (Id.,15) e as senhoras de boa família passavam a procurar uma ocupação. "Por falta de pessoal, os bondes e os metrôs, pela primeira vez, empregavam mulheres para o controle das passagens" (Ibid.), mas sem dinheiro "os habitantes do subúrbio eram obrigados a fazer longas caminhadas a pé" (Ibid.). A comida passou a desaparecer dos armários das famílias, Mestre em Filosofia pela Universidade de São Paulo. Residente em São Paulo - SP. E-mail: 
"o preço do pão, da farinha de trigo, da carne, da manteiga, do açúcar e do café, havia dobrado. $\mathrm{O}$ das batatas e dos ovos havia triplicado. O poder de compra dos operários diminuíra globalmente em um terço" (Id., 16); nessa situação "a maioria dos cidadãos carecia de produtos de primeira necessidade. Quando era possível o abastecimento, o racionamento instituído dava direito a um ovo, 2,5 quilos de batatas e 20 gramas de manteiga por semana" (Ibid.). Mas, "não somente se morria de fome, sobretudo nas cidades, era preciso se adaptar ao sistema de penúria para se vestir" (Ibid.). Nas cidades, "a iluminação a gás era racionada" e "para economizar carvão nos meses de inverno, os fogões só eram acesos nas refeições" (Ibid.). As doenças se espalharam, "a mortalidade por tuberculose subiu de 11,9\% em 1914 para 17,3\% em 1917 (...) Surgiram casos de tifo e cólera. Milhares de crianças, de mulheres e de velhos sucumbiram à epidemia de gripe que grassou em 1918" (Id., 17). A situação de miséria em que o país se encontrava não deixou de ser acompanhada por uma convulsão social. "Consequência inevitável dessa miséria: a corrupção e o roubo. (...) No primeiro semestre de 1918, o montante de indenizações pagas pelas companhias de seguros contra roubo equivalia a quase quatro vezes o de todo ano de 1915" (Ibid.,16). Já as greves, com influência da Liga Espartaquista1", "por vezes violentas, haviam aumentado a partir do final de 1917. Mais de um milhão de manifestantes tinham desfilado nas ruas das grandes cidades em janeiro de 1918. Em Berlim, a polícia havia reagido, matando inúmeros operários. Nas fábricas, a consciência política crescera" (Ibid., 24). Neste contexto é que, a monarquia dava lugar ao nascimento a uma nova república alemã; um parto difícil com inúmeros obstáculos que se abateu sobre uma nação inteira, mas que foi sofridamente vivenciada por uma geração de jovens, como Benjamin na época, que entre ver seus corpos pilhados nas trincheiras do passado ou pelas ruínas do presente, sacrificara suas esperanças. Sobre a experiência de

\footnotetext{
1 Durante a Primeira Guerra Mundial pudemos ver uma intensa disputa sobre a posição da Alemanha nos combates. A Liga Espartaquista nasceu deste contexto, da dissidência do Partido Social Democrata Alemão (SDP) que se afastou dos majoritários como um movimento de oposição à guerra apoiada pela direção do partido, fundando o Partido Socialista Independente (USDP), mas, ao mesmo tempo, um braço mais radical e revolucionário dos independentes. Como embrião do Partido Comunista Alemão (KDP), a Liga Espartaquista teve como principais nomes Karl Liebknecht e Rosa Luxemburgo, que como porta vozes da paz, tornaram-se os dirigentes mais populares das trincheiras. (Cf. RICHARDS, 1988, 24).
} 
miséria de sua geração, marcada pela Guerra, Benjamin escreve mais tarde (em Experiência e Pobreza, 1933):

\begin{abstract}
Uma geração que de 1914 a 1918 viveu uma das experiências mais monstruosas da história universal (...). Pois jamais houve experiências tão radicalmente desmentidas pela realidade: as estratégias, pelas guerras de trincheiras; as econômicas, pela inflação; as físicas, pela fome; as éticas, pelos donos do poder. Uma geração que ainda fora à escola de bonde puxado por cavalos viu-se exposta numa paisagem onde tudo, exceto as nuvens, havia mudado, e em cujo centro, num campo energético de explosões e correntes destruidoras, estava o minúsculo e frágil corpo humano. (BENJAMIN 1986a, 195)
\end{abstract}

As dificuldades impostas pela crise econômica marcada pelo desemprego, por uma hiperinflação e violência política que afetavam o contexto social alemão durante o pós-guerra não foram indiferentes ao jovem Benjamin que, por sua vez, não apenas sentiu na pele as consequências desse turbilhão, como acompanhou esse período como um pensador engajado de seu tempo. No que tange a sua pesquisa, esse período de instabilidade política e econômica interferiu não apenas em sua condição material, Ihe impondo obstáculos financeiros para realização de seu trabalho, como também passou a repercutir teoricamente na própria investigação, de maneira que pode extrair o político do estético no Barroco. Durante os anos 20, há uma série de cartas em que Benjamin reclama da sua situação financeira e de ainda depender de seus pais. Na Suíça, para onde havia emigrado ${ }^{2}$ para evitar o engajamento no exército alemão, tratar de uma doença crônica, terminar seu doutoramento e elaborar sua dissertação, Benjamin escreve para Ernst Schoen uma carta onde comenta de suas dificuldades financeiras (Carta à Schoen, 5/12/1919). "Em Berna, contra todas as minhas expectativas mais ousadas, oferecem-me a possibilidade de continuar minha Habilitation. Uma situação que não posso aceitar se não arrumar um emprego condigno e convenientemente remunerado para minha mulher, que nos permita viver na Suíça” (Benjamin Br. II, 63). Morando primeiro em St. Moritz e Zurique, depois fixando-se em Berna, Benjamin acreditava encontrar um lugar onde pudesse

\footnotetext{
${ }^{2}$ A primeira emigração de Benjamin seguiu o caminho de muitos outros intelectuais judeus na época como Hermann Hesse, Hugo Ball, Ludwig Klages e Ernest Bloch que buscavam um refúgio da Guerra. A oposição de Benjamin em relação a Guerra e sua dispensa devido a um problema de saúde que o levou para a Suíça pode ser acompanhado nos relatos de sua amizade com Scholem e por seu biógrafo. (Scholem, 1989, p.48-49; Witte, 2017, 35).
} 
prosperar seus projetos, "tudo, com exceção daquele pouco com que faço minha vida viver, tudo aquilo de que tentei me aproximar nos últimos dois anos foi decadência, e me encontro aqui em muitos sentidos salvo: liberado da crua anarquia, da ausência da lei do sofrimento" (Witte 2017, 35), manifestava alívio de se encontrar em segurança, mas também distanciamento de Berlim e do contato paternal que tanto o fazia sofrer. No ar dos alpes, Benjamin encontrara a tranquilidade para redação de seu projeto, "um espaço livre em face ao plano de seu pai, que tentava convencer o jovem de 27 anos a arranjar uma profissão 'burguesa' após o término de seus estudos. Benjamin, por sua vez, queria seguir a vida como intelectual independente, com objetivo de obter o mais cedo possível sua livre-docência, o que pressupunha um apoio financeiro constante da parte de seu pai" (Id, 41). De uma família de negociantes bem-sucedidos, Benjamin não previa dedicação a necessidades exteriores a sua sobrevivência, mas a crise econômica não perdoara nem mesmo àqueles que nunca tiveram preocupações financeiras, os filhos da alta burguesia industrial e comercial alemã. De repente, a gravidade da situação material do país colocava em risco seu modo de vida e sua pretensão a carreira acadêmica, de grande prestígio social, mas destinada a poucos privilegiados com capital cultural e estabilidade econômica. A inflação na Alemanha o obrigou a renunciar a sua permanência na Suíça e voltar, com mais de trinta anos, para a casa dos pais em Berlim, onde passou a se sustentar com a compra e venda de livros (carta à Rang de 2/10/1922). Contudo, vivenciando a emergência da situação familiar, Benjamin não particularizou a frustração de seus planos, sabia que "as dificuldades de sobreviver como intelectual e escritor autônomo na Alemanha do pós-guerra e da inflação eram consideráveis (...) num país beira à falência" (BOLLE, 2000, 164) e, assim, percebeu seus problemas como consequência da carreira escolhida em um tempo de declínio econômico e queda do prestígio dos mandarins alemães. Dizia que "quem na Alemanha faz um trabalho intelectual sério está ameaçado de fome da forma mais séria" (WITTE, 2017, 56), a experiência de pauperização que afetava a sua família, o seu trabalho, e o contexto geral da sociedade alemã aparece em seu desabafo a seu orientador Florens Christian Rang (carta à Rang de 24/02/1923): "Estes últimos dias de viagem pela Alemanha levaramme à margem do desespero e me fizeram olhar dentro do abismo" (BENJAMIN Br. II, $317)$; as suas viagens a Heidelberg, onde primeiro pensou em submeter sua livre- 
docência, Frankfurt, onde a submeteu, impuseram em Benjamin a imagem de um país desorganizado economicamente pela inflação e politicamente instável pelas reações ao parlamentarismo weimariano e pela a ocupação da região de Ruhr ${ }^{3}$. Ali se desenhava o primeiro embate de Benjamin com as anomalias sociais de seu tempo. Neste momento é que, o já crítico e militante, Walter Benjamin passa a se preocupar também com as bases materiais da produção cultural; "nesses anos, despertou o seu interesse para textos literários que, ao invés de camuflarem a violência, a encararam" (BOLLE, 2000, 156). A sua pesquisa, sobre o barroco alemão, ganha um novo caminho. Em uma carta de 1924, destinada a Gerson Scholem (carta à Scholem de 22/12/1924), Benjamin comenta os contornos políticos aos quais estavam ganhando a sua pesquisa, após uma viagem a Capri ${ }^{4}$. Segundo Benjamin a viagem:

\begin{abstract}
despertou em mim a vontade de desenvolver no meu pensamento os momentos atuais e políticos, em vez de camuflar com argumentos antiquados - e se possível, a título de experiência, de forma mais radical. Naturalmente, isto significa que a exegese das obras literárias alemãs, na qual, na melhor das hipóteses, se trata essencialmente de conservar e restaurar o autêntico contra as falsificações expressionistas recua para um plano secundário. Enquanto não tomar conhecimento de textos com um significado e uma totalidade completamente diferentes, na posição de comentador que é a minha, arrancarei dentro de mim uma política. (BENJAMIN Br. II, 511)
\end{abstract}

Aos poucos, a preocupação que o filósofo tinha com os assuntos estéticos e, em particular, a percepção do drama barroco no contexto alemão, esquecido como

\footnotetext{
${ }^{3}$ A ocupação de Ruhr se deu em 1923, um ano terrível para a instabilidade política da socialdemocracia weimariana, devido ao atraso da entrega de carvão para franceses e belgas decorrentes das indenizações da Guerra. Um relato detalhado deste episódio pode ser visto em Claude Klein (1995, 45,46).

${ }^{4}$ Esse novo modo de ver o seu trabalho pode ter a ver com seu encontro com Asja Lacis, uma dramaturga revolucionária de Riga, que dirigia o teatro infantil de Moscou. Em suas memórias, ela conta que quando o conheceu, "Ele estava mergulhado no trabalho da Origem do drama barroco alemão. Quando disse que se tratava de uma investigação da tragédia barroca alemã no século XVII, que só poucos especialistas conhecem essa literatura, e que tais tragédias nunca são representadas - eu fiz uma careta: Para que se ocupar de literatura morta? (...) Naquela época, as suas respostas não me satisfaziam. Perguntei-lhe se encontrava também analogias entre a visão de mundo dos dramaturgos do barroco e do expressionismo e que interesses de classe elas exprimiam. Ele respondeu de forma imprecisa e acrescentou ainda que andava a ler Lukács e começava a se interessar por estética materialista. Nessa altura, em Capri, não entendi bem a ligação entre alegoria e poética moderna. Agora, retrospectivamente, compreendo de modo clarividente como Walter Benjamin se apercebeu dos problemas formais da modernidade" (Tiedemann; Schweppenhäuser 2013, 286). A influência do bolchevismo de Lacis, impulsionou e aprofundou do ponto de vista teórico a sua leitura de História de consciência de classes de Georg Lukács que tinha feito um ano antes, foi a partir daí que Benjamin se aproximou de um ideal marxista de mundo, que por sua vez, não foi nada ortodoxo.
} 
um gênero literário menor, como um mero simulacro da tragédia grega, ganhou novos contornos com a compreensão dos ecos da política do século XVII que ressoavam na sua geração, fazendo do trágico, expressão da política de seu tempo; uma expressão que veio a se confirmar com profundidade no conturbado nascimento da República de Weimar e na barbárie que sucedeu a sua instituição, sobretudo, após sua breve duração (1919-1933). O âmbito da política que reverberava historicamente no presente como tragédia passa a ser o ponto de partida para o estudo do Barroco que, igualmente, tem, na dimensão histórica assumida e representada por seus personagens, a tragicidade em evidência (em Drama barroco e tragédia, 1916):

A apreensão mais profunda do trágico talvez deva tomar como ponto de partida não só e nem tanto a arte, mas também e bem mais a história. Porém, pelo menos é de se supor que o trágico designe um limite tanto do reino da arte quanto do âmbito da história. Entre a grandiosidade no sentido histórico e a tragicidade há uma conexão de natureza essencial - que, no entanto, não se dissolve em identidade (BENJAMIN, 2014d, 59)

Com esse olhar que não se limita à forma empírica e vazia do tempo, é que Benjamin encara a experiencia da história, contemplando em todas as suas infinitas direções, podendo ver no presente, o passado. No reino da arte a tragédia barroca e a estética expressionista de seu tempo carregavam uma conexão essencial, "tenho a impressão de que nos últimos dois séculos, nenhuma época revela, na sua sensibilidade artística, tamanha afinidade com a busca de um estilo da literatura barroca como a dos nossos dias. Interiormente vazios ou profundamente dilacerados, exteriormente absorvidos por problemas técnicos formais que, à primeira vista, não se encontravam com questões existenciais do seu tempo" (BENJAMIN, 2011, 44), a partir da linguagem carregada em expressão dos poetas contemporâneos, Benjamin via o exagero alegórico dos literatos do barroco, mas mais que isso a mesma situação dilacerante de seu tempo histórico com o século XVII, uma época de terríveis guerras e doenças, onde do ponto de vista histórico a transcendência estava bloqueada. "Nesse dilaceramento, o presente espelha determinados aspectos da mentalidade barroca até o nível pormenor das práticas artísticas" (Id, 46), mas apesar dos paralelos, Benjamin também encontrava situações limites, as transformações materiais entre os dois períodos aprofundaram-se no drama contemporâneo:

O literato barroco sentia-se totalmente ligado ao ideal de uma estrutura política absolutista, apoiada pela Igreja de ambas as confissões. A atitude de 
seus herdeiros de hoje, quando não é hostil ao Estado, revolucionária, é pelo menos marcada pela ausência de qualquer ideia de Estado. Enfim, para lá de muitas analogias, não podemos esquecer de uma grande diferença: na Alemanha do século XVII, a literatura, por pouca importância que a nação lhe desse, foi decisiva para o seu renascimento. Já nos vinte anos de literatura alemã que aqui se referem para explicar o despertar por interesse por aquela época correspondem a um período de decadência, por mais promissora e fecunda que a época possa ser. (Ibid.)

Benjamin não deixava de notar no interesse que sua época tinha no barroco também uma busca mistificada pela identidade nacional, orientada ideologicamente para interesses conservadores e nacionalistas, como representada na figura do poeta Stefan George ${ }^{5}$ e sua escola. Muito mais que transpor um período a outro, Benjamin considerava que retomar o Barroco a partir da história era uma atitude política a se tomar em seu tempo, em oposição a história mítica que resguardavam do barroco no processo de formação do espírito nacional. Contudo, constituir-se historicamente tampouco tinha a ver com uma narrativa linear em que cada acontecimento está inscrito em uma cadeia de causalidades. "Articular o passado historicamente não significa conhecê-lo 'tal como ele propriamente foi'. Significa apoderar-se de uma lembrança tal como ela lampeja num instante de perigo" (BENJAMIN, 2005, TESE VI, 65), na concepção benjaminiana de história, a imagem do passado apareceria para o sujeito histórico nos momentos de tensão histórica, em que a memória dos que sucumbiram, pudesse ser resgatada nos gritos dos oprimidos e não na neutralidade pretensa do historiador que o narra, como queria Leopold von Ranke. O historiador prussiano, conhecido por representar o passado 'tal como ele realmente foi' era o maior nome do modo como se desenvolveu a historiografia alemã. A pretensão rígida e científica que pressupunha um discurso histórico neutro, em certa medida partilhava de uma preocupação que Benjamin também possuía e combatia em relação aos anacronismos e deturpação ideológica da história da literatura contemporânea; tal como Benjamin, Ranke concordava que "na forma como os eruditos alemães viam a questão, o maior pecado do historiador era tratar o passado como uma coleção de

\footnotetext{
${ }^{5}$ No período pós-guerra uma série de antologia sobre a poesia barroca do século XVII passou a ser recuperada com entusiasmo. Entre a Guerra dos Trinta Anos e os destroços da Primeira Guerra, o leitor alemão encontrou a mesma desolação lutuosa do barroco alemão. Nisto se destacou o círculo formado em torno do poeta Stefan George que exaltava o völkisch alemão e o heroísmo dos mártires como forma de recuperar o patriotismo e o orgulho nacional ferido. (Cf. Benjamin, 1986b; Rouanet, 1984, 2627)
}

Mestre em Filosofia pela Universidade de São Paulo. Residente em São Paulo - SP. E-mail: michel.amary@gmail.com 
exemplos a ser usada para glorificar o homem, o progresso e o presente para construir máximas genéricas da arte de governar, ou para tabular os avanços da ciência e da razão" (RINGER, 2000, 104). Mas, com a ingênua neutralidade que depositava nos fatos, "ele queria ser histórico, descrever épocas, instituições e indivíduos do passado o tanto quanto possível em seus próprios termos, em vez de julgar o papado da Renascença pelos padrões de Lutero e a Idade Média pelos padrões atuais" (Id, 105), o que, para Benjamin, era impossível de ser realizável de modo distanciado, sem o partilhamento da experiência histórica original e sem sua interpretação nos fatos. Por sua vez, Benjamin, no início do século $X X$, está inserido em um momento intelectual que passa a contestar esta fundamentação causal da filosofia da história, mistificada na ideia de progresso, ideologizada na posição centrista e com pouco espaço interpretativo de acesso ao passado, desta maneira que apresenta o conceito de origem (Ursprung) assim definido no livro do Barroco:

\begin{abstract}
Apesar de ser uma categoria plenamente histórica, a origem (Ursprung) não tem nada em comum com a gênese (Entstehung). Origem não designa o processo de devir de algo que nasceu, mas antes aquilo que emerge do processo de devir e desaparecer. A origem insere-se no fluxo do devir como um redemoinho que arrasta no seu movimento o material produzido no processo de gênese. $O$ que é próprio da origem nunca se dá a ver no plano factual, cru e manifesto. O seu ritmo só se revela a um ponto de vista duplo, que o reconhece, por um lado como restauração e reconstituição, e por outro como algo incompleto e inacabado. Em todo o fenômeno originário tem lugar a uma determinação da figura através da qual uma ideia permanentemente se confronta com o mundo histórico, até atingir a completude na totalidade da história, (BENJAMIN, 2011, 34)
\end{abstract}

Como em seus escritos sobre linguagem e até mesmo a percepção alegórica do barroco onde se percebe a não identificação entre significante e significado, representação e representado no discurso histórico, Benjamin também assume a posição de que os fatos não representam por si só a verdade histórica de uma ideia. Distantes temporalmente do presente, os fatos históricos não deixam de receber um polimento desse sujeito da história que é ao mesmo tempo objeto e produto de um tempo histórico, na visão do filosofo era preciso superar esse imperativo liberando a história ao reino das ideias e das significações, recuperando o conceito de verdade que se apresenta na ideia e não em sua representação. A representação da história não passava de um sistema que buscava a identificação dos acontecimentos históricos com uma ontologia do presente, um esquema em que o filósofo via apenas 
uma instrumentalização do conhecimento para domínio de narrativas históricas de pretensão universal que deixavam de apreender a verdade expressa também em suas particularidades. Ao deixar o modelo representativo de lado, Benjamin abria-se para a subjetividade da interpretação dos fenômenos que contornava em um jogo de revelação e crítica, ao procurar evidenciar as relações da parte com o todo, não se tratava simplesmente de identificar um singular em similitude ao universal, mas se deixar ver o universal que se mostra pelo singular. De tal maneira, o método dedutivocausal, linear e progressivo da historiografia convencional daria lugar a uma dualidade originária do discurso histórico. Benjamin percebeu que "as unidades constitutivas do discurso histórico surgem a partir de uma afinidade especial entre o posterior e o anterior, a partir de uma dupla perspectiva do tempo representado e que representa" (BOLLE, 2014, 536). De um lado, contemplada do presente, a representação da história aparece como 'pré-história', de outro, do ponto de vista do passado, a história aparece como pós-história. Entre passado e presente não há nenhuma continuidade, por isso se faz necessário o salto do tigre onde a verdade histórica se mostra abruptamente como momento histórico originário que faz a ponte entre tempos distantes. Nesse sentido que a história é inconclusa e inacabada, o fazer histórico consiste em arrancar do passado aquilo que está esquecido, emparelhá-lo no presente, e reconstruí-lo como forma de ato de reconhecimento. Assim a categoria de origem se levanta contra a historiografia dos fatos:

\footnotetext{
É conhecida a fórmula de Hegel: 'tanto pior para os fatos'. No fundo, o que ele quer dizer é: cabe ao filósofo estabelecer as conexões entre essências e, estas permanecerem inalteradas, ainda que no mundo dos fatos elas não se manifestem de forma pura. (...) Com esta reflexão parece estar superada, para os mais elevados objetos da filosofia, a distinção entre quaestio juris e a quaestio facti. (BENJAMIN, 2011, 35)
}

Circunscrito em fazer uma história da filosofia do trágico, ante uma filosofia da história do trágico que seguia-se desde Schelling, Benjamin considera que a história da arte e da literatura não existem como disciplinas independentes, mas apenas como um fator da história geral, de modo que nas artes o discurso histórico nada mais seria que um médio entre a forma artística e seu conceito de representação, entre o efeito da obra e sua recepção, o acontecido, com o tempo de agora, os conteúdos objetivos da história e sua apresentação da verdade filosófica. Nesse sentido, que para Benjamin pode-se estabelecer o lugar privilegiado do filósofo na interpretação da Mestre em Filosofia pela Universidade de São Paulo. Residente em São Paulo - SP. E-mail: 
história, ele tem jurisdição para percorrer a verdade e estabelecer conexões dos fatos, que não falam por si só; ante a questão de fatos, o percorrer da verdade dá para a filosofia a questão de direito. Como vimos, no fundo, o debate epistemológico sobre a história não deixa de estar contaminado pelas questões centrais desenvolvidas pela metafísica idealista e filosofia da linguagem, a relação entre o particular e o universal. Por isso, nessa fase, ainda não podemos considerar os diversos antagonismos da concepção histórica de Benjamin de dialética no sentido hegeliano, apesar de sua citação. Claramente oposta aos procedimentos dedutivos causais provenientes da tradição historiográfica alemã e da própria história em progresso que podemos extrair de Hegel, no livro do barroco, sua noção de história é assumidamente monadológica, ao considerar estas oposições coexistindo, sem mascarar seus limites, contrastes e rupturas, na própria obra de arte que por sua vez, leva dentro de si a miniatura do todo.

Esse percurso metodológico é fundamental não apenas para a crítica do barroco, mas, sobretudo, porque estabelece as bases de compreensão de Benjamin ao redefinir as fronteiras entre o passado e o presente, espelhando o conturbado momento político da república alemã ao absolutismo do século XVII. Não por menos é que se pode apontar que "o conceito e o método desse procedimento foram tomados da obra Teologia política: quatro capítulos sobre a doutrina da soberania, publicada por Carl Schmitt em 1922, que Benjamin cita várias vezes" (WITTE, 2017, 64), enquanto o jurista procurava a reconstituir a conexão entre os motivos teológicos e a organização política do século XVII, do mesmo modo, Benjamin procurava ligação entre o teatro e a literatura barroca com o soberano: "O princípio metodológico fundamental de Benjamin poderia ser formulado da seguinte forma, transformando-se uma proposição de Carl Schmitt: a imagem metafísica que uma determinada época faz do mundo tem a mesma estrutura daquilo que a ilumina imediatamente como forma de expressão literária" (Id, 65). A inspiração curiosa de um jurista reacionário e, posteriormente, teórico importante do regime nazista no pensamento de Benjamin, um intelectual de uma esquerda crítica e revolucionária, expressa ao mesmo tempo a oposição vigorosa, tanto da direita, quanto da esquerda, à república de Weimar. Contudo, essa inspiração não é acrítica. Benjamin debate seriamente com Schmitt o 
poder do soberano decidir sobre o estado de exceção, e aí o palco do barroco dá lugar ao próprio ato político que culminou no terceiro Reich.

Desse modo, "no universo do Trauerspiel, drama barroco, a República de Weimar é transportada para a dimensão da liberdade alegórica, na qual tudo pode ser dito. A alegoria não é, para Benjamin, imagem ou representação de uma ideia abstrata, mas um texto com força política, que remete à história presente, a crítica à atualidade, possibilitando ao drama assimilar como conteúdo as próprias condições de sua época" (DYMETMAN, 2002, 142). Não faltavam indícios ao filósofo da semelhança entre seu tempo e seu objeto de estudo, "o universo barroco pode ser visto como uma alegoria do estado total qualitativo de Schmitt, no qual a missão do príncipe é implantar um reino estável" (Ibid.) lacrando a história e protegendo o mundo de toda e qualquer perspectiva de mudança ou transcendência, mas também como uma "crítica a cristalização de tendências táticas que desde o início do século vinham dividindo a esquerda" (Ibid.) desde a Segunda Internacional (1889-1916), entre reformistas e revolucionários, partidos e sindicatos, socialdemocratas e espartaquistas, que culminou nos assassinatos nunca investigados de Karl Liebknecth e Rosa Luxemburgo, onde a história aparece repetida e recontada, petrificada enquanto natureza. A partir de agora, devemos mostrar na letra do autor como "a desolação posterior à Guerra dos Trinta Anos e o presente marcado pela derrota e pela miséria" apresentavam "a mesma dicção torturada, a mesma violência verbal, a mesma temática do pessimismo" (ROUANET, 1984, 26), fazendo do barroco uma alegoria que assimila como "conteúdo as próprias condições de sua época" (Ibid.), destacando, das muitas afinidades que Benjamin percebeu entre o período do pósguerra e o drama barroco, a discrepância entre a construção mítica da tecnologia e do ideário patriótico alemão na guerra com a experiência traumática da derrota e da instabilidade política, social e econômica do período weimariano.

\section{A Primeira Guerra Mundial: os ethos da guerra como mito}

Primeiro, ganham destaques em seu pensamento as marcas das experiências sem precedentes da Primeira Guerra Mundial (em Teoria do fascismo alemão, 1930) um acontecimento de proporções devastadores que explodiam como manifestação de 
uma modernidade impulsionada pela ideia de progresso e por suas inovações tecnológicas e deixaram uma ferida exposta na identidade alemã, a "germanidade" (Deutschheit):

a última guerra tem uma característica especial. Ela não foi somente a guerra das batalhas de material, foi também a guerra perdida. Perdida em um sentido muito particular, pelos alemães. Outros povos podem afirmar que lutaram uma guerra a partir de sua substância mais íntima. Mas nunca nenhum afirmou que a perdeu a partir de sua substância mais íntima. O que há de singular nesta última fase do confronto da guerra perdida que desde 1919 convulsiona a Alemanha, é que justamente a derrota que é mobilizada pela germanidade. (BENJAMIN, 1996, 64,65)

Com o fim da guerra, a Primeira República alemã passou a remontar os acontecimentos e narrar as experiências de horror vividas por soldados e sobreviventes; entretanto, neste balanço histórico de narrativas partilhadas predominou um modo heroico de contar a guerra que derivava do período guilhermino, dando vazão a uma literatura pró-guerra e pró-violência representada por romances como Nação contra nação (Volk wieder Volk) (1912) de Walter Bloem e o diário de guerra Tempestade de aço (In Stahlgewittern) (1922), de Ernest Jünger. Para Benjamin, a historiografia representada na coletânea Guerra e Paz de Jünger mostrava enfaticamente que com a campanha alemã, não se perdeu apenas a substância material em disputa na guerra, a superioridade técnica e alguns mercados, a derrota foi vivida como perda da substância espiritual da nação. Devemos lembrar que a "germanidade" foi inscrita ao longo dos séculos pela cultura da guerra no espírito alemão, a guerra foi vivenciada desde a formação do Estado Alemão como uma experiência que fortalecia o sentimento do patriotismo e de potência a que aspirava a jovem nação, se perpetuando como um ritual. Em sua biografia de uma nação, Os alemães ((Studien über die Deutschen), Nobert Elias nos mostra como o ethos guerreiro contribuiu para constituição da identidade nacional do país. Durante a conquista da Europa por Napoleão, a invasão à Prússia criou, nos alemães, um sentimento de franqueza e impotência do país perante as grandes potências do mundo que se manteve até a campanha da Guerra Franco-Prussiana. Essa sensação foi superada apenas na demonstração de força nas batalhas de unificação em 1871, ali os alemães tinham uma resposta clara e inequívoca da mudança de status do país e da transição que passavam em sua identidade. "A mudança ocorreu através de uma 
curta série de vitorias militares" (ELIAS, 1992, 114) em países vizinhos como Áustria (Guerra Austro-Prussiana), Dinamarca (Guerras de Schleswig ou Guerra dos Ducados) e a própria França (Guerra Franco-Prussiana), de modo que em detrimento a "ideia de que preservar a consideração pelos outros, o amor e a solicitude de ajudar o outro" (Ibid.) se constituiu no alemão um ideário patriótico de glorificação da força e da guerra que repercutiu na vida social do império e nas aspirações imperialistas durante a Primeira Guerra Mundial. Com a vitória nacional ocorrendo sob liderança de uma nobre aristocracia e cortes militares que deixou a burguesia ascendente da industrialização em segundo plano, os valores e a tradição guerreira se compuseram nos estratos políticos, econômicos e na classe média alemã. De um lado, "uma vez que os anseios de unificação tinham sido realizados através de guerras vitoriosas sob a liderança militar da aristocracia, foi aduzida a conclusão de que a guerra e a violência também eram bons e esplêndidos instrumentos políticos" (Id, 167), na disputa interna da nação, um instrumento que serviu tanto aos vitoriosos aristocratas quanto seções importantes da burguesia. Esta, por sua vez, não deixou de adaptar a disciplina militar ao seu processo de industrialização, inserindo-a nas relações de trabalho: "em certa medida, o ethos militar definiu o ethos do trabalho para os próprios trabalhadores" que se transformaram nessa relação, fazendo com que, "em última análise, o ethos do trabalho nacional e a consciência dos indivíduos, estivessem igualmente em harmonia com a distribuição de forças desse tempo" (Id, 188). Como indivíduos, os trabalhadores passaram a se associar ao guerreiro, rejeitando sentimentos humanos, considerados piegas, e mostrando força moral suspeita, brio e coragem, "o indivíduo tinha que se mostrar duro" (Id, 189). No seio social, a ideologia em voga após a unificação era de que "a Alemanha era fraca; agora é forte e devemos fazer tudo o que estiver a nosso alcance para nos tornarmos ainda mais fortes, tanto militar quanto economicamente" (Ibid.), e que foi abalado com sua derrota. A perda da guerra tornouse pior que a própria guerra, pois se "o vencedor conserva a guerra, o derrotado deixa de possuí-la, o vencedor a incorpora em seu patrimônio, transforma em coisa sua, o vencido não a tem mais, é obrigado a viver sem ela" (BENJAMIN, 1996, 65), de modo complementar o seu desfecho "altera o modo de existência para nós" (lbid.). Desse modo é que a derrota que se manifesta como perda de identidade, para Benjamin, o mal-estar espiritual que abrange a época, coloca o alemão em analogia com o homem 
barroco que viu na ausência de Deus, seu mundo em decomposição. Perdida em uma espécie de negação do presente, a historiografia do pós-guerra buscava recolher os cacos e reconstituir a lembrança desse mundo de sangue que tinha se esfarelado em ruínas. Benjamin percebeu nessa tentativa a mistificação da guerra e do herói:

Com lança chamas e trincheiras, a técnica tentou realçar os traços heroicos
no rosto do idealismo alemão. Foi um equívoco. Porque os traços que elas
julgavam heroicos eram na verdade traços hipocráticos da morte. Por isso,
tão profundamente impregnada por sua própria perversidade, a técnica
modelou o rosto apocalíptico da natureza e reduziu-a ao silêncio, embora
pudesse ter sido a força capaz de dar-lhe voz. A guerra como abstração
metafísica, professada pelo novo nacionalismo é unicamente a tentativa de
dissolver a técnica de modo mítico e imediato, o segredo da natureza
concebida em termos idealistas, em vez de utilizar e explicar esse segredo,
por um desvio, através da construção de coisas humanas. (BENJAMIN, 1996,
70).

Sob a poeira do ideal patriótico e do heroísmo, Benjamin viu, na historiografia de seu tempo, o falseamento das tragédias gregas na descrição heroica das cenas de guerra e encontrou nos versos de Stefan George, a concepção barroca do heroísmo na guerra. Enquanto se cantava a saga de heroísmo e do destino que diziam que "os mortos de guerra (...) ao tombarem passam de uma realidade imperfeita para uma realidade perfeita, da Alemanha temporal à Alemanha eterna" (Id, 68), a realidade mostrava para essa geração que "o início da escuridão, no deflagrar da guerra, apenas veio a desencadear sobre suas cabeças o que há muito se adensava em seus corações, e representava para essa geração (...) a essência mesma da Natureza" (BENJAMIN, 1986, 148); ela "estava predestinada à morte". No caráter dos heróis já se podia encontrar a diferença entre o drama barroco alemão que foi compreendido equivocadamente como caricatura da tragédia ática, enquanto o herói grego transcende ao enfrentar os deuses e por isso se torna imortal, os jovens alemães nas trincheiras apenas expressavam a necessidade da natureza e do destino, não tendo controle sobre suas vidas, caminhando para a morte que nada muda. Nas palavras queixosas dos combatentes, Benjamin apreendeu que a forma da guerra deixara 0 corpo a corpo pela "guerra material, cegamente mecânica" (BENJAMIN, 1996, 70), em sua expressão técnica e material "a guerra hoje em dia não é mais conduzida, mas administrada" (Id, 66), mas, ao mesmo tempo, "a guerra foge a qualquer economia regida pela inteligência, em sua razão existe algo de sobre- humano, desmedido (...) que hoje já se tornou mítico, canalizado para tarefas que ultrapassam os limites do 
que hoje pode ser compreendido" (Id, 64). Na perda da suposta racionalidade, Benjamin encontrava a situação daquele homem do barroco alemão que não rompe com as artimanhas da natureza e instaura a nova ordem histórica, pelo contrário, reproduzindo-se como uma sucessão de tragédias, a guerra torna-se eterna e a técnica, destino. O fetiche da técnica longe de indicar em sua transitoriedade a direção única dos acontecimentos sociais e humanos no caminho do progresso e da racionalidade, petrificava e mortificava a temporalidade histórica no sentido da natureza onde a mudança não indica nada mais que uma repetição circular dos acontecimentos: o mito desencantado pela forma histórica, voltava como história natural. Em seu ensaio sobre Stefan George (Stefan George em retrospectiva, 1933), Benjamin mostra que o poeta acompanhado daqueles que morreram na guerra, canta, para o tribunal da História, a Natureza como a força dominante daquele tempo, uma força superior que por mais que o homem busque controlá-la pelo desencantamento do mundo a partir da técnica, "jamais chega a dominar, da qual, no melhor dos casos, copia alguns hábitos, com o qual vive em permanente luta, da qual precisa se defender e proteger" (BENJAMIN, 1986b, 147). Por mais que a racionalidade cientifica e histórica se coloque no horizonte como Razão e História, "a Natureza jamais perde seus poderios sobre os horrores" (Id, 147), a violência e os modos mais eficientes de abater um inimigo até podiam ser conquistas da técnica, mas eram expressões da Natureza e não da História. Assim, não eram os soldados mortos em ação que entravam na imortalidade por seu heroísmo na guerra, mas a própria técnica que com lança-chamas e trincheiras se colocou misticamente como história natural.

Não passou despercebido aos olhos de Benjamin, que na exaltação fetichista da guerra escondia-se o domínio da técnica como aparente domínio do homem sobre a natureza. Nem tão evidente assim, Benjamin destaca que o progresso e o desenvolvimento técnico assumiram um protagonismo sobre a guerra e sobre as vidas humanas. O prenúncio da Guerra vinha estampado na exaltação do progresso da técnica na modernidade na estética Futurista de Filipo Marinetti:

No manifesto de Marinetti sobre a guerra colonial etíope pode-se ler: Há vinte e sente anos que nós, futuristas, nos erguemos contra o fato da guerra ser considerada antiestética. De acordo com isso verificamos que: a guerra é bela porque, graças as máscaras de gás, aos horríveis megafones, aos lançachamas e aos tanques pequenos, conseguem fundamentar a supremacia do homem sobre a máquina subjugada. A guerra é bela porque inaugura a tão 
sonhada metalização do corpo humano. A guerra é bela porque enriquece um prado florido com orquídeas flamejantes e metralhadoras. A guerra é bela porque reúne numa sinfonia tiros de espingarda, de canhão, as pausas do cessar-fogo e os perfumes e odores dos cadáveres em decomposição. A guerra é bela porque cria novas formas arquitetônicas, como a dos grandes tanques das esquadrilhas geométricas de aviões, das espirais de fumo das aldeias incendiadas e muitas outras coisas. Poetas e artistas do futurismo, lembrai-vos desses fundamentos de uma estética da guerra, para que vossa luta por uma nova poesia e nova escultura, seja por eles iluminadas (BENJAMIN, 2017, 46-47)

Com essas palavras atribuídas ao vanguardista, Benjamin iluminava os esforços de estetização da política, isto é, a tentativa de manipulação da estética para fins ideológicos da promoção e disputa de poder político que tardiamente, só foi perceber na apoteose fascista que desencadeou a Segunda Guerra Mundial. Contudo, o cerne da estetização da guerra já podia ser lido em 1909 no Manifesto Futurista e sua mistificação da técnica e exaltação da mecanização do homem que o desposava de humanidade. Lá, lê-se que pelo desprezo a intelectualidade, "fétida gangrena de professores, de arqueólogos, de cicerones e antiquários" (Marinetti, 1909, 11, 7) pela qual a Itália devia se libertar com "uma violência arrebatadora e incendiária" (Ibid), o futurismo cantaria "o gesto destruidor dos libertários" (Id. 9, 6) que se achavam e "as belas ideias pelas quais se morrem" (Ibid.) tais como soldados na guerra, "às grandes multidões agitadas pelo trabalho, pelo prazer ou pela sublevação; cantaremos" (Id, 11, 7), dizem "as marés multicores e polifônicas das revoluções nas capitais modernas" (lbid.). Acreditavam que com desenvolvimento da racionalidade cientifica e tecnológica às vistas nos últimos anos nas metrópoles modernas, "finalmente a mitologia e o ideal místico foram superados (...). Eis sobre a terra, a primeiríssima aurora. Não há nada que iguale o resplendor da vermelha espada do sol que esgrima pela primeira vez nossas trevas milenares" (Id. 4). Rapidamente, dentre os cantos do ronco do automóvel e "seu hálito explosivo" (Id. 4, 6), "o vibrante fervor noturno dos arsenais e dos estaleiros incendiados por violentas luas elétricas" (Id. 11, 7), "as locomotivas de largo peito que pateiam sobre os trilhos como enormes cavalos de aço" (Ibid), e "o voo rasante dos aviões, cuja hélice freme ao vento, como uma bandeira, e parece aplaudir como uma multidão entusiasta" (Ibid) passamos em uma "velocidade onipotente" (Id 8,6) à "glorificar a guerra - única higiene no mundo - o militarismo, o patriotismo" (Id 9, 6). Fez-se a sombra novamente. "L'automobile c'est la guerre" (BENJAMIN, 1996, 61) lembrava Benjamin a frase de Leon Daudet Mestre em Filosofia pela Universidade de São Paulo. Residente em São Paulo - SP. E-mail: 
sobre o Salão do Automóvel para mostrar, como já demonstra o futurismo italiano, a relação íntima entre o desenvolvimento tecnológico e a guerra. Para Benjamin:

\begin{abstract}
O que estava na base dessa surpreendente associação de ideias era a concepção de uma aceleração dos recursos técnicos, dos tempos, das fontes de energia, etc. os quais em nossa vida particular não encontram aproveitamento pleno, adequado e, no entanto, insistem para se justificar. Na medida em que renunciam à interação harmônica, justificam-se na guerra, a qual com suas destruições, prova que a realidade social não estava madura para fazer da técnica seu órgão, e que a técnica não estava suficientemente forte para dominar as forças elementares da sociedade. Sem querer diminuir a importância das causas econômicas da guerra, pode-se afirmar que a guerra imperialista, em seu aspecto mais duro e mais funesto, é determinada também pela enorme discrepância entre os gigantescos meios tecnológicos por um lado e o mínimo conhecimento moral destes meios por outro (BENJAMIN, 1996, 61)
\end{abstract}

Ao contrário daqueles que cantavam a glória da superioridade técnica, Benjamin aponta que a técnica escapa da compreensão humana e dos limites do entendimento que pensava controlá-la. Ela não se apresenta como instrumento que permite ao homem o controle da natureza, tampouco representa a capacidade do homem controlar a si mesmo, segundo algumas tradições filosóficas; nos ditames da revolução industrial a técnica passou de ser um meio de controle do homem sobre outros homens para, em seu atual desenvolvimento, inverter a posição de domínio, fazendo do homem seu próprio instrumento. Ao retomar Friedrich Nietzsche, Benjamin rememora a concepção cartesiana que compara a "descoberta de um cientista a uma sequência de batalhas com a natureza" (BENJAMIN, 2006, 415), já vemos nessa frase a razão se desposar da natureza em uma simbologia de guerra; é sobre essa concepção que nasce a racionalidade técnica que, sob a ilusão de controlar a si mesmo, irá fazer da natureza um meio instrumentalizado pela civilização. "O saber que é poder não conhece barreira alguma, nem a escravização da criatura, nem a complacência dos senhores do mundo" (ADORNO; HORKHEIMER, 2006, 18) com objetivo de colocar os homens na condição de senhores, o domínio da natureza foi apenas um passo para o domínio dos homens sobre outros homens. "O que os homens querem aprender da natureza é como empregá-la para dominar completamente ela e outros homens. Nada mais importa." (Ibid). A sociedade aparece como um prolongamento da natureza a ser dominada, uma segunda natureza que tem na dominação "a técnica como essência desse saber, que não visa conceitos e imagens, nem o prazer do discernimento, mas o método, a utilização do trabalho de 
outros, o capital" (Ibid.). Ao ironizar o ponto de vista imperialista que vê na "dominação da natureza (...) a finalidade de toda a técnica" Benjamin pergunta de maneira irônica "quem confiaria num mestre da palmatória que declarasse como finalidade da educação a dominação das crianças pelos adultos? (...) Assim também a técnica não é dominação da natureza: é a dominação da relação entre a natureza e a humanidade" (BENJAMIN, 2013d, 65).

Contudo, contrariamente ao que o comemorado progresso da técnica poderia sugerir, a técnica inverte completamente o jogo com a humanidade: "a guerra imperialista é a revolta da técnica que recolhe no material humano, os direitos que a sociedade lhe retirou do seu material natural" (BENJAMIN, 2017, 47). Benjamin nota que "como a avidez de lucro da classe dominante pensava satisfazer a sua vontade à custa dela, a técnica traiu a humanidade e transformou o tálamo nupcial num mar de sangue" (BENJAMIN, 2013d, 65). Com tanques, trincheiras e submarinos, Benjamin assistiu ao desenvolvimento da tecnologia a serviço da barbárie; e mais além, um misticismo enraizado no século $X X$ que fez da técnica um mito, inquestionável, intransponível, irrefutável. Como a violência que liberada não permite mais controle, a técnica tem como fim a sua reprodutibilidade material, como posto e reposto ela é apenas repetição, sem objetivo a não ser seu próprio autopotenciamento, e na guerra ela se desenvolve mecanicamente em um rito de destruição. Reproduzindo-se como uma sucessão de tragédias, onde os homens são mortos e sacrificados pela técnica, a guerra torna-se eterna e a técnica, natureza cega, sem objetivo final ou fim último que se repete a cada combate. Contra a despreocupação e desorientação que consideram essa experiência moderna da técnica irrelevante, Benjamin alerta que a técnica:

voltará sempre a se impor, e então nem povos nem gerações lhe escaparão, como se viu, da forma mais terrível na última guerra (Primeira Guerra Mundial), que foi uma tentativa de religação, nova e inaudita, com as forças cósmicas. Massas humanas, gases, energias elétricas foram lançados em campo aberto, correntes de alta frequência atravessaram as paisagens, novos astros apareceram no céu, o espaço aéreo e as profundezas dos mares ressoavam de hélices, e por toda parte se escavavam fossas sacrificiais na terra-mãe. Esse grande assédio feito ao cosmos consumou-se pela primeira vez à escala planetária, isto é, no espírito da técnica. (...). Nas noites de destruição da última guerra, uma sensação semelhante a felicidade do epilético abalava a estrutura da humanidade. E as revoltas que se the seguiram foram a primeira tentativa de dominar o seu novo corpo (BENJAMIN, 2013, 65) 
Longe da ilusão de que a técnica poderia ser uma força que acenderia a natureza à linguagem em uma composição harmoniosa, equilibrada e bem estabelecida entre a natureza, o cosmo e os homens, como víamos nos antigos, com força, a técnica modelou "o rosto apocalíptico da natureza e reduziu-a ao silêncio" (BENJAMIN, 1996, 70), de vez em quando rompido pelo estopim de uma bomba. As fantasias de Charles Fourier segundo a qual a técnica, "longe de explorar a natureza, libera as criações que dormem, como virtualidades, em seu ventre" (BENJAMIN, 2005 TESE XI, 100), encerrando o ciclo repetitivo da natureza a partir de uma experiência libertadora que a permitisse reconciliar com o trabalho humano, tomou o sentido contrário: onde se queria reconciliação tivemos a tomada de distância da natureza, onde se queria libertação tivemos o domínio e a exploração. Como nova aura da modernidade, a técnica estabelece uma relação conflituosa com os cosmos e impõe violentamente sua tentativa de reconexão com o corpo da humanidade. Um corpo que pela razão instrumental da técnica sentiu um inexorável estranhamento para sua condição de natureza, tornando-se objeto morto, e também para sua condição de gênero, o reconhecimento de si mesmo enquanto humanidade, transformando-se em coisa passível de ser dominada, manipulada, descartável e até mesmo sacrificada pela guerra, triturado pelas engrenagens da fábrica ou pela funcionalidade própria desse mundo que a tecnologia transformou em máquina e segue sem questionamentos em sua lógica interna de produção e reprodução orientado pela ideia de expansão e progresso. Paul Scheerbart em Lesabendio foi quem conseguiu saudar "de forma mais risonha e alegre" (BENJAMIN, 1986a, 197) esta questão. Ele retrata "de que modo nossos telescópios, nossos aviões, e foguetes transformaram os homens tradicionais em criaturas novas, dignas de atenção e respeito. Aliás, essas criaturas já falam uma língua totalmente nova" (Ibid.) e o que apresentam como decisivo e inconfundível na sua linguagem é "a tendência construtiva e arbitrária, contrastando com a dimensão orgânica (...) pois eles rejeitam a semelhança com os homens" (Ibid.) é essa caracterização que opõe a dimensão natural do homem rejeitada pelo caráter construtivo do progresso e arbitrário da técnica que marca a experiência de miséria que nos abateu: o afastamento da humanidade com os cosmos que não consegue mais reencontrar, e que vê na galvanização de sua tentativa desesperada de se religare, "ao se reavivar a astrologia e a sabedoria da ioga, a 
Christian Science e a quiromancia, o vegetarianismo e a gnose, a escolástica e o espiritismo (...) diante da porta a crise econômica e atrás dela, a sombra da próxima guerra" (Id. 196-198), a autentica experiência que é permitida ao homem contemporâneo parido de uma cesariana na era técnica. Quando as forças cósmicas deixaram de manifestar a vontade dos deuses para tomar forma de um relógio em que o tempo passa a ser precisamente medido e explicado por essa racionalidade técnica que dá corda ao seu movimento, a violência, quando "na época de Homero, a humanidade oferecia-se em espetáculo aos deuses olímpicos (...) se transforma em espetáculo para si mesma" (BENJAMIN, 1996, 196), é pervertida na guerra como um pacto de sangue, um sacrifício mítico (registrado como espetáculo da imagem pela primeira vez em alcance planetário, nos conflitos de 1914-1918) capaz de estabelecer a nova ordem cósmica do mundo. Estava inaugurada a guerra da técnica.

Apartados de sua natureza e conectado na tomada à sua armadura e armas contemporâneas, não foi surpreendente para Benjamin prever que, em posse de sua segunda natureza, o mito da racionalidade técnica e do progresso, a humanidade em breve se encontraria em outra guerra. Cloroacetofenona, difenilamina, cloroarsina e sulfeto de dicloroetila, "as designações anteriores serão tão populares na próxima guerra quanto "trincheira", "submarino", "Berta Gorda" e "tanque" foram na passada. Para os vocábulos químicos difíceis de pronunciar serão adotadas em poucos dias abreviações" (BENJAMIN, 2014a, 69). Um relatório da Liga das Nações mostrava para ele que a tecnologia da próxima guerra seria química, "a guerra vindoura terá um front espectral. Um front que será deslocado fantasmagoricamente ora para esta, ora para aquela metrópole, para suas ruas, diante da porta de cada uma de suas casas. Ademais, essa guerra, a guerra do gás que vem dos ares, representará um risco literalmente de tirar o fôlego" (Ibid.), mais preocupados com os danos do espetáculo mortífero que as explosões causam, o gás lacrimogênio, "o mais humano dos novos recursos" (id. 70) até parecia simpático àqueles que não conhecem seu efeito; entretanto, contra gases não há defesa, além de mortal ele se espalha ampliando o front para cidades e populações civis criando um terror similar à psicose que passariam longe das utopias de Wells e Verne, como diz Benjamin. "Nas ruas de Berlim, espalha-se sob o belo e radiante céu primaveril um cheiro parecido com o das violetas. Isto dura alguns minutos. Logo em seguida, o ar se tornará sufocante" (Ibid.), 
em poucos minutos as pessoas perderão a visão e se não escaparem morrerão sufocadas. "Tudo isso poderá suceder um dia sem que se veja no céu qualquer aeronave nem se perceba o ronco de uma hélice" (Ibid.); nos termos atuais o que especialistas militares chamam de guerras sem-baixas (as guerras dos drones que dizima homo sacer).

\section{A república de Weimar: o estado de exceção como naturalização da história}

A Primeira Guerra Mundial deixou para a Alemanha de Benjamin, além dos túmulos e miséria material do país uma herança psicológica traumática representada pela ameaça a identidade nacional e sua substituição pela mistificação dos processos acelerados da ciência e da técnica. Se Benjamin observava ali, o germe que desembocaria na próxima guerra, foi a conturbada formação da República de Weimar o casulo que a gestou. Ao tomar todo esse período como um espelhamento das histórias narradas pelo barroco alemão, onde a história é um fóssil, Benjamin vislumbra a ascensão de Adolf Hitler em uma fotomontagem de John Heartfield, da qual gostava muito, intitulada 'História Natural Alemã' (Deutsche Naturgeschichte: Metamorphose) de 1934. Ali, a Alemanha era retratada como na teoria darwinista da evolução e do progresso em três etapas biológicas de uma mariposa que "sugere uma ligação causal entre a república de Weimar e o fascismo" (BUCK-MORSS, 2002, 8990). Estavam representados como uma larva, Friedrich Ebert, primeiro chanceler da república, como um casulo Paul von Hindelburg, seu último chanceler e burocrata do império, e como mariposa o próprio Hitler. Em referência a essa metamorfose Benjamin apontava que: "o espírito revolucionário da burguesia alemã se transformou na crisálida da qual brotou mais tarde a borboleta do nacional-socialismo" (id. 90). reformismo de Weimar não tinha rompido diretamente com o regime anterior. Enquanto, de olho na Rússia, a esquerda mais radical "quisesse ver, na revolução de novembro, o ‘fevereiro' alemão, esperando outubro” (KLEIN, 1995, 27), por outro lado, "a maior preocupação de Ebert é evitar a ampliação da Revolução" (id. 26). Era interessante para os sociais-democratas que estavam no poder que o anseio revolucionário se acalmasse para que o país se tornasse governável. A sua posição sustentava uma ambiguidade de posição que se manifestou em um duplo aparelho 
estatal: "De um lado, uma administração clássica nunca foi alterada. De outro, um Conselho de Operários e de Soldados" (id. 28) que "de boa-fé serviram de aval revolucionário para um governo cuja maior preocupação era precisamente frear a revolução" (id. 24). Não por menos, Benjamin confere ao conformismo socialdemocrata a responsabilidade pelo colapso ulterior: "não há nada que tenha corrompido tanto o proletariado alemão quanto a crença que ele nadava com a correnteza" (BENJAMIN, 2005 Tese XI, 100). Nesse panorama pragmático da socialdemocracia, Benjamin notava que "a construção da vida social passa nesse momento muito mais pela força dos fatos do que pelas convicções. Concretamente, de fatos que nunca e em lugar nenhum chegaram a transformar-se em fundamento de convicções" (BENJAMIN, 2013e, 9). Contudo, se o governo socialdemocrata com apoio majoritário dos trabalhadores jogava as convicções para cima, no tecido social, os partidos à esquerda e os contrarrevolucionários do império injetavam óleo para fazer funcionar a engrenagem de suas máquinas:

Quanto maior for a hostilidade de alguém em relação a tradição, tanto mais
implacável será a necessidade que tem de submeter a sua vida privada às
normas que deseja elevar à condições legisladoras de uma situação social
futura (...). Já os homens que sabem em consonância com as mais antigas
tradições de sua classe ou de seu povo, coloca de vez em quando a sua vida
privada ostensivamente em oposição as máximas que intransigentemente
defendem na vida pública e enaltece no seu íntimo, sem quaisquer problemas
de consciência, o seu próprio comportamento como mais convincente prova
da inabalável autoridade dos princípios que professa. Nisso se distingue duas
categorias de políticos: o anarcossindicalista e o conservador (BENJAMIN,
2013b, 17)

A diferença gritante entre a esquerda espartaquista e a socialdemocracia vinha do apego quase que conservador aos ideais germânicos, uma união que já havia sido realizada durante a Primeira Guerra justificada como a defesa da nação ofendida. Mais do que as próprias convicções, a formação de Weimar estava completamente em consonância com os ethos tradicionais abalados na guerra. Do ponto de vista da germanidade, a república buscou resgatar o orgulho ferido da nação. A cidade de Weimar não foi escolhida como capital da república apenas pela destruição de Berlim, mas sim por ter como seus autóctones mais ilustres J. W. Goethe e F. Schiller. Além da guerra, o alemão tinha na cultura um traço muito forte de sua germanidade, como Benjamin ilustrou nas palavras de Gottfried Keller ao fazer uma autoimagem da Alemanha pela citação de seus pensadores:

Mestre em Filosofia pela Universidade de São Paulo. Residente em São Paulo - SP. E-mail: michel.amary@gmail.com 
Os alemães são por sua natureza um povo docente e discente, uma raça eleita da cultura, e não só isso, mas também foram eleitos para serem os zeladores da cultura, mestres-escolas e filósofos do gênero humano, eles não podem, portanto, ser virtuoses da ação, não podem ser pessoas políticas modelares (...) como os ingleses e os franceses (...). Os alemães deixariam de ser uma grande nação, em termos da história da cultura, se ambicionassem ser uma grande nação no sentido da política, da diplomacia e da história bélica. (BENJAMIN, 2014c, 89)

Não podemos desvincular a escolha de Weimar de um forte aparelho conceitual que se desenvolveu desde o idealismo alemão, a saber, os conceitos de Kultur e Zivilization, que se acentuaram em distância após o término da guerra. Oriundos da revivescência cultural da Bildung do século XVIII, originalmente "a palavra alemã Kultur foi adaptada de cultura anime de Cícero por Samuel Pufendorf e Gottfried von Herder" com "o significado de cultural pessoa, referia-se ao cultivo da mente e do espírito" (RINGER, 2002, 96). Mais tarde, tomou um novo conceito, passando a ser entendida "em seu sentido mais geral de síntese de todas as realizações do homem civilizado na sociedade" (Ibid.) que se contrapunha à perspectiva francesa e fisiocrata de Zivilization, que representava os "arranjos sociais e intelectuais do homem" (Ibid.), isto é, a polidez social e cortesia que para as cortes alemãs, ressentidas desde as invasões napoleônica, pareciam como importação e dominação cultural. Kant fazia muito bem esta distinção entre civilização e cultura ao inferir "a primeira com boas maneiras e amenidades sociais, e a segunda com arte, saber e moralidade. Na sua opinião, sua época era civilizada demais, sem ser realmente culta" (id. 97), um dote proveniente apenas dos alemães. Como a Kultur, Zivilization também se modificou conceitualmente, logo deixando a polidez superficial para se referir ao conhecimento genérico mundano, "o termo civilização, ampliou-se naturalmente para abarcar todos os resultados do progresso externo em economia, tecnologia e organização social, enquanto Kultur continuou a representar a condição interior e as realizações dos homens cultos" (id. 98). Neste ponto também víamos a rejeição do idealismo tipicamente alemão ao conhecimento pragmático e empirista anglo-francês, como Elias nota: "Zivilization significa algo de fato útil, mas apesar disso um valor de segunda classe compreendendo apenas aparência externa dos seres humanos" (Elias 1994, 24); ela aborda a organização política e a econômica, mas não sua pretensa totalidade transcendental reportada aos fatos intelectuais, artísticos e teológicos. Dessa maneira, a capital intelectual da Alemanha não somente representava 
lembranças da "germanidade", dos valores clássicos do idealismo alemão e do romantismo que calcaram o pensamento e a sua cultura, como também o ideal de grandeza desse povo que apesar da potência de seu pensamento, não deu vazão a realizações políticas e econômicas, não viu sua revolução burguesa passar ${ }^{6}$ e mantendo-se preso ao conservadorismo e a tradição feudal, viu uma rápida e repentina industrialização querer se colocar como novo ethos da "germanidade" abalada

Como valor de um povo que construiu sua identidade nacional em torno da Kultur, a sua oposição a Zivilization se acentuou durante a Grande Guerra, "travada contra a Alemanha em nome da "civilização", e, posteriormente, em 1919 "por causa da autoimagem que os alemães tiveram que redefinir na situação criada pelo tratado de paz" (Elias 1994, 27). Nas imposições do Tratado de Versalhes, a nação sentiu seu orgulho ferido. Concebido como uma humilhação, o texto elaborado considerou a Alemanha responsável por provocar a guerra, uma responsabilidade que era tanto moral como financeira, e impôs uma grande compensação pelos custos do conflito e restrições significativas ao seu território. Na perspectiva econômica coube a Alemanha uma pesada indenização, "A delegação alemã havia proposto determinar no Tratado o montante das indenizações e fixá-las em 100 bilhões de marcos-ouro pagáveis em cinquenta anos. Os aliados não concordaram" (KLEIN, 1995, 34), esses valores seriam aumentados em conferências posteriores sufocando a economia alemã para o abismo que se deu em 1923 e aumentando a desconfiança aos planos de recuperação, Plano Dawes e Plano Young7, propostos pelos Aliados em 1924. "No plano territorial, a Alemanha perdia, além de todas as suas colônias (Togo, Camarões e Sudoeste Africano), a Alsácia-Lorena, uma parte do Schleswig, Dantzig, Memel, importantes territórios na Polônia, parte da baixa Silésia, a região de Eupen e de

\footnotetext{
${ }^{6}$ Ao contrário dos franceses e dos ingleses, a Alemanha nunca passou por uma Revolução Burguesa em seu processo civilizatório e desenvolvimento industrial. O mais próximo que a Alemanha chegou de uma Revolução dessa espécie foram a Reforma Protestante promovida por Martinho Lutero e a Revolução de 1848 que a modernizou perpetuando o poder de sua elite agrária (DYMETMAN, 2002, 8). Esses dois momentos fizeram não apenas de sua burguesia extremamente rural, prosaica e conservadora no que se refere aos costumes e a política, como também fizeram de sua revolução política, teológica.

${ }^{7}$ Esses planos buscavam o combate a inflação na perspectiva das relações externas, estabelecendo como metas a restauração do marco e a dinamização da economia. Uma descrição mais precisa da estratégia economia que traziam e suas críticas a esquerda e a extrema direita podem ser acompanhadas na analise de Claude Klein $(1995,53)$
} 
Malmédu. No total, perto de 1/8 de seu território anterior a 1914" (Ibid.). No militarismo, o armistício teve como consequência "a desmilitarização da margem esquerda do Reno (...) abolição do serviço militar obrigatório, limitação do exército em cem mil homens, armamento reduzido - era autorizada apenas uma artilharia de 288 peças e marinha reduzida a quase nada" (Ibid.). Na disposição do cumprimento do desarmamento pela Alemanha, Benjamin observa a hipocrisia da comunidade internacional que continua a aumentar o seu poderio milita: "a persistência com que, na execução do Tratado de Versalhes pela Alemanha, foram questionados ridículos requisitos militares não tem só um aspecto desagradável, mas, sobretudo algo de sumamente perigoso. Porque ela desvia a atenção pública do único problema atual do militarismo internacional" (BENJAMIN, 2014a, 72). Dito e feito! Os alemães perceberam na perda de sua soberania militar, perante um mundo que se armava, um perigo iminente. Assinado em 1919, com o governo socialdemocrata em difícil situação para negociar, o Tratado não foi bem aceito pela população, principalmente entre os militares que dispunham desde o império de grande prestígio. A redução drástica do número de oficiais que antes beiravam aos 400 mil homens, muitos ainda jovens e agora desempregados, foi o grande corpo social que formaram os Freikorps e os grupos de mercenários e paramilitares da direita, responsáveis por convulsões sociais, tentativas de golpes e assassinatos durante Weimar

Já o ethos da técnica apontado por Benjamin, foi a aposta assumida desde o começo pela socialdemocracia para reconstrução do país. Nos embates que envolveram a promulgação da Constituição de Weimar em 1919, o consenso foi estabelecido na fé depositada em uma cadente ideologia do progresso. Benjamin reconhecia aí, no culto da industrialização, da tecnologia, e do progresso, o caráter conservador da socialdemocracia:

O conformismo que, desde o início, sentiu-se na casa da socialdemocracia, adere não só a sua tática política, mas também as suas ideias econômicas (...) O desenvolvimento técnico parecia-lhe o declive da correnteza em cujo sentido acreditava nada. Daí era um só passo até a ilusão de que o trabalho fabril, que se insere no sulco do progresso técnico, representaria um feito político. A velha moral protestante do obrar celebrava, em forma secularizada, a sua ressureição entre os operários alemães. (...) Ele já mostra os traços tecnocráticos que serão encontrados, mais tarde, no fascismo. (BENJAMIN, 2005, TESE XI, 100) 
Benjamin que pouco tinha se interessado pela Revolução Russa em 1917 e criou simpatia pela esquerda espartaquista tão somente a assinatura dos embargos contrários a guerra, aqui, muito mais tarde e já marxista condena o conformismo político das reformas socialdemocratas, mas, sobretudo por seu conteúdo econômico predominantemente técnico, que já criticara desde a juventude. Na busca por resgatar na república a unidade nacional a socialdemocracia assumira a responsabilidade da integração democrática das classes sociais ao fechado jogo político alemão. Neste âmbito, ainda que buscasse uma conciliação de classe que atravancava a modernização das estruturas de poder, pode-se dizer que tentou-se estabelecer uma reforma progressista do ponto de vista democrático, concentrando-se na pluralidade de interesses, de direitos individuais relacionados a um espectro mais liberal a direitos sociais que pressupunham a assistência do Estado na promoção da igualdade material. Contudo, o primeiro e grande passo para consolidação de uma nova unidade nacional era conquistar a estabilização econômica do país em reconstrução. Em uma posição positivista da economia e do socialismo, os socialdemocratas pautaram sua política econômica no desenvolvimentismo de um capitalismo organizado na república, influenciada pelo economista Rudolf Hilferding. A curta estabilidade no início dos anos 20 foi o suficiente para a ampliação do projeto de racionalização da economia alemã por parte do Estado. "O progresso técnico começou a ser visto como o caminho das melhorias sociais futuras" (BERCOVICI, 2004, 53) garantindo a eficácia e a eficiência da sociedade e seus recursos. Esse caminho que se manteve em disputa mesmo em seus primeiros anos, logo desmoronou com a crise econômica já em 1923 que se seguiu após a Grande Depressão de 1929, com hiperinflação e altas taxas de desemprego formando nas classes médias a massa para o nazismo, que Benjamin acompanhou com preocupação em seu Panorama Imperial:

\footnotetext{
A desesperada fixação nas ideias da segurança e da posse, que dominaram décadas passadas, impede 0 homem comum de se aperceber de extraordinárias estabilidades, absolutamente novas, que são base da situação atual. Como a relativa estabilidade dos anos de guerra lhe foi favorável, ele acha que tem que considerar instável toda situação que lhe retire posses. Mas nunca as situações estáveis tiveram também de ser situações agradáveis, e já antes da guerra havia camadas sociais nas quais a situação estável significava miséria estável (...). Um estranho paradoxo: as pessoas quando agem pensam no interesse pessoal mais mesquinho, mas ao mesmo tempo, são mais do que nunca determinadas no seu comportamento pelo instinto das massas. E nunca hoje os instintos das
} 
massas se enganaram tanto nem foram tão estranhos a vida. (BENJAMIN, 2013c, 18)

Se no culto ao trabalho, propagado pela socialdemocracia, Benjamin percebia a estrutura religiosa do capitalismo (cf. BENJAMIN, 2014b, 21) que estranharia o indivíduo de si mesmo, de sua alteridade e de sua classe, transmutando-o pela técnica em máquinas que servem, tanto para apertar botões nas câmaras de gás, como para moer corpos, aqui de uma maneira muito mais pragmática, ele testemunhava as transformações da subjetividade humana em decorrência das relações econômicas e da miséria. "Vai-se perdendo a liberdade de diálogo. Antigamente era natural, entre pessoas que dialogavam, ir ao encontro do ponto de vista do outro; hoje, pergunta-se logo pelo preço dos sapatos ou do guarda-chuvas. Qualquer conversa cai fatalmente no tema das condições de vida e do dinheiro" (BENJAMIN, 2013c, 21). Não sem justificativa, os alemães tinham que se preocupar. Se a inflação persistia desde antes do fim da Guerra, ela se tornou extremamente grave durante o ano de 1923, vítima da instabilidade política interna e das pressões econômicas internacionais com suas indenizações. Neste ano o marco entrara em colapso: "No início do ano de 1923 eram precisos 18.000 marcos para adquirir um dólar. No final do mês de janeiro, já passava para 50.000 (...) em junho, 150.000. Em julho, a barreira do milhão será rapidamente ultrapassada, nos meados de agosto, 4 milhões. No final de setembro, 160 milhões. A barreira do bilhão será rapidamente ultrapassada" (KLEIN, 1995, 46). Benjamin não ficara indiferente para a pobreza que se alastrava pelas ruas de Berlim, "não é por acaso que se fala de miséria nua e crua (...) Tornou-se impossível viver numa grande cidade alemã, onde a fome força os mais miseráveis a viver das notas de banco com que os transeuntes procuram tapar uma nudez que os fere" (BENJAMIN, 2013c, 19). Com a inflação, Benjamin viu que "o calor vai abandonando as coisas" e que "os objetos de uso cotidiano repelem as pessoas, de forma mais lenta e insistente" (Id. p.21) mudando o registro das próprias relações humanas. "Os indivíduos têm de compensar a sua frieza com seu próprio calor para não congelarem ao seu contato, e tem que agradar com extremo cuidado os seus espinhos para não se esvaírem em sangue. Não esperam qualquer ajuda do próximo." (Ibid.). Essa hiperinflação devastadora "significou a ruína econômica sobretudo para aqueles grupos sociais que já se achavam em desvantagem comparativa em uma época de rápida 
industrialização" (RINGER, 2000, 73) em três níveis. Primeiro, destruiu a poupança em dinheiro enriquecendo banqueiros e agiotas; segundo penalizou empregados com salários já defasados e ajudou empregadores, e por fim trouxe perdas em transações comerciais e trocas de mercadorias. Ao mesmo tempo em que a ilusão da "primavera alemã eternamente adiada" se tornava, "apenas mais uma das manifestações da natureza alemã em decomposição", as pessoas fugiam da percepção da decadência de maneira que "os indivíduos encurralados nos limites deste país perderam a noção do contorno da pessoa humana" (BENJAMIN, 2013c, 21). Assim os problemas econômicos demoliam com a socialdemocracia e inflava a construção do mito da Grande Alemanha e do conservadorismo nacional, alimentando o fascismo.

Enquanto a socialdemocracia alemã apostava no tecnicismo político e econômico de Karl Kautsky e Rudolf Hilferding, que "como verdadeiros políticos só fazem projetos a prazo" (BENJAMIN, 2013a, 42), Benjamin acionava o Alarme contra o incêndio prevendo que se não fosse interrompido o rastilho dessa história naturalista e evolucionista "até um momento rapidamente calculável da evolução econômica e técnica (a inflação e a guerra de gás parecem assinalá-los), então tudo estará perdido" (Ibid.). A ingerência da ideologia do progresso pela socialdemocracia não apenas enfraqueceu uma esquerda revolucionária socialista e sua "revolução inacabada" de 1918 como fortaleceu a "revolução conservadora" ou ortodoxa que trocou o sinal da Constituição de Weimar. A disputa interna entre as esquerdas não foi poupada pelas forças contrarrevolucionárias da direita. No mesmo ano de 1923, com a crise política e econômica, a Baviera proclama um estado de exceção em seu território investindo contra o Reich que se recusa a empregar forças armadas contra os bávaros. Nesse momento, ainda que os poderes ditatoriais estivessem nas mães de von Kahr, Hitler aparece em cenário nacional como um grande vencedor político da crise bávara. Ele já tinha estabelecido, como agitador político, grande base de apoio na Baviera, no fim da crise, um desfile nazista termina com 16 mortos. Hitler é ferido, foge e futuramente é julgado e preso, tornando-se um "mártir" reconhecido pela extrema-direita (KLEIN, 1995, 48-49), capitalizando votos que transfiguraram a composição do Parlamento e mais profundamente a chave de interpretação da Constituição de Weimar.

Do ponto de vista jurídico-filosófico, a Constituição de Weimar girou em duas frentes: uma hegeliana e outra neokantiana. A vertente hegeliana entendia que "a 
Constituição é a lei da vida política global de um Estado, ou seja, está ligado a um "ser" político do Estado" (Cf. BERCOVICI, 2004, 7) uma compreensão mais próxima dos socialdemocratas que confundiam o Estado como ente político e a sua forma legal. De outro havia uma vertente que orbitava em torno de posições neokantianas próximas ao Hans Kelsen e ao positivismo do Círculo de Viena segundo a qual a "Constituição é uma regra de direito que apenas regula o comportamento estatal, estando ligada ao dever ser do Estado" (Ibid.). Como estatuto jurídico a sua base não é o ente político do Estado, mas a norma a qual estaria limitada, cabendo apenas regular o comportamento dos agentes estatais, interpretação mais ligada ao liberalismo. Com a vitória do Partido Social Democrata, prevaleceu a interpretação hegeliana da Constituição que não se manteve alterada até o agravamento da crise econômica e da agitação da extrema-direita e seus ataques separatistas. A partir daí a interpretação jurídica hegeliana que favorecia a socialdemocracia, mostrou sua outra face no conservadorismo antiliberal da teoria jurídica de Carl Schmitt ${ }^{8}$. De repente, a Constituição se viu contra a República. O que não seria surpresa dada a ingenuidade socialdemocrata. "O Reich alemão é uma república afirmava o artigo 1‥ Mas é mister observar que é a única vez em todo texto constitucional que se emprega a palavra república" (KLEIN, 1995, 35). Conservador e forjado dos anos do império, o povo alemão apenas tolerava a república, Weimar era uma "república sem republicanos" (DYMETMAN, 2002, 11). Aproveitando-se da característica "bicefalista do Executivo que introduz uma forma particular de regime parlamentar" - onde temos "um presidente do Reich, eleito por sufrágio universal para sete anos de governo, com poderes amplos, podendo notadamente submeter a um referendo popular as leis votadas pelo Reichstag (e que ele desaprove)" (KLEIN, 1995, 35) e ao seu lado "um governo chefiado pelo chanceler do Reich, nomeado pelo presidente e responsável

\footnotetext{
${ }^{8}$ Ao conceber que o soberano é aquele quem decide sobre o estado de exceção, como expresso no artigo 48 da Constituição de Weimar, Schmitt reafirmava seu caráter antiliberal, destituindo a soberania como prerrogativa do poder legislativo que a exerce partir das leis que regulam normatizam o Estado como representantes da sociedade, para identificar a legitimidade da decisão na função executiva do presidente do Reich, oficializando um Estado Total. A concepção jurídica de Schmitt não se contrapunha a institucionalidade da presença do Estado, concebido na socialdemocracia na ampliação do Estado Social, mas a tomava, a partir de uma perspectiva conservadora, pela força de um Estado Total contrário, tanto ao conflito característico das democracias liberais, pensado na lógica do inimigo e não do adversário, como as liberdades individuais, que ao seu ver ameaçavam a unidade política do Estado, muito cara no contexto.
} 
perante o Reichstag" (Ibid.) que pode ser dissolvido ilimitadamente pelo presidente do Reich - a teoria decisionista schmidittiana, segundo a qual confere ao soberano o poder de decisão sobre o estado de exceção, ganha um caráter positivo de Estado Total que se consolida no surgimento do nazismo na realização de seu artigo 48 . 0 artigo 48 da Constituição de Weimar, em seu parágrafo 2, previa que:

\begin{abstract}
Se um Estado não cumpre as obrigações a ele impostas pela Constituição ou pelas leis do Reich, o presidente do Reich pode impô-las com ajuda das forças armadas. Em caso de graves distúrbios ou ameaças à ordem pública e a segurança, o presidente do Reich pode tomar as medidas necessárias para sua restauração, intervindo, se preciso com a ajuda das forças armadas. Para isso, pode, temporariamente, no todo ou em parte ab-rogar os princípios fundamentais que constam nos artigos: 114, 115, 117, 118, 123, 124, 153. (DYMETMAN, 2002, 109)
\end{abstract}

A questão sobre o direito de decidir do soberano abre um extenso debate intelectual entre Benjamin e Schmitt que perpassa obras como o próprio drama barroco alemão e textos como Para uma crítica a violência, a oitava Tese sobre a História (Benjamin) e Hamlet oder Hecuba: Die Einbruch der Zeit in das Spiel (Schmitt), inspirando futuramente outros personagens como Jacques Derrida e Giorgio Agamben. A posição do presidente do Reich nesse artigo expressa o mesmo dilema que Benjamin identificou no monarca barroco do século XVII que, em sua posição de soberania, deveria decidir sobre o estado de exceção, proclamando-o em nome do bem-estar e da paz. No barroco alemão, Benjamin empresta o conceito moderno de soberania que encontra na Teologia Política de Carl Schmitt para caracterizar o soberano como a figura intocável que deve domar o processo histórico que aparece inconstante, instável e ao acaso. Contudo dá uma resposta crítica ao jurista. Benjamin não deixa de indicar a contradição entre estado de exceção e bemestar, própria da modernidade filosófica, encontrando-a na presença sob Maquiavel, na tensão entre a legalidade e a manutenção da ordem que só poderia se resolver pela ação do soberano na suspensão temporária da lei. Em suas origens no direito romano, deve-se frisar o caráter temporário da suspensão da lei, quando o estado de exceção aparecendo como um instrumento jurídico para defender o país de uma ameaça externa, suspende temporariamente o Estado de Direito perante a avaliação do Congresso. Na modernidade filosófica do século XVII o caráter temporário que limitaria o poder absoluto do soberano desaparece porque a sua própria autoridade é 
absoluta e porque seu poder não é regulado constitucionalmente, é fundamentado na sua condição teológica que percebe o seu corpo de rei próximo de Deus. O aparecimento de um estado de exceção na Alemanha do século XX ganhava um contorno excepcional na contradição de seu próprio tempo, uma vez que além do dilema do soberano que estava acima da lei, a Constituição de Weimar fundada pelos ideais republicanos e democráticos mantinha dentro de sua ordem, o estado de exceção, mantendo-se durante todo o período até o nazismo em que se tornou permanente ${ }^{9}$. A possibilidade de convivência e coexistência em uma mesma ordem constitucional da república e do estado de exceção, nos mostra como a Modernidade, ao contrário do que o lluminismo propôs, não superou ainda a união entre o teológico e o político. No Estado Moderno "tudo ocorre como se a Constituição tivesse sido concebida tendo em mente o estado de exceção, e a energia republicana não passasse de um estado de exceção represado" (MATOS, 2003, 51), utilizando a violência como meio de Direto, o Estado bloqueia qualquer possibilidade de interrupção do tempo histórico, como manutenção da ordem é apenas mais do mesmo. Nessa chave que podemos ler sua VIII tese sobre a história, onde se lê: "A tradição dos oprimidos nos ensina que o estado de exceção no qual vivemos é regra geral. Precisamos chegar a um conceito de história que dê conta disso" (BENJAMIN, 2005, TESE VIII, 83). Um ponto em comum da história era que tanto a sua interpretação liberal e conservadora como a leitura marxista influenciada pelo materialismo histórico. Influenciado por Hegel seguia o caminho da história em progressão, evolução continuidade do tempo que acaba por não romper radicalmente com o que chamou de tradição dos oprimidos. Da tradição dos oprimidos partilhavam tanto a decadente classe-média alemã como o melancólico homem do barroco que

\footnotetext{
9 Em A Ditadura (Die Diktatur, 1921) Schmitt diferencia dois tipos de ditadura para justificar as diferenças entre o estado de exceção antigo e moderno como mecanismo político. Como ditadura comissária, o estado de exceção protege a Constituição, dialeticamente, ele suspende provisoriamente a aplicação do ornamento jurídico para sua manutenção. Como ditadura soberana não se suspende a Constituição apelando aos seus mecanismos, ao contrário, se suspende para substituí-la por outro ordenamento jurídico a ser implantado, a ditadura soberana deriva do poder constituinte e não da Constituição. Na Alemanha, como bem mostra Giorgio Agamben a partir de suas leituras de Benjamin, tínhamos uma zona de anomia em que o estado de exceção funcionou tout a court com roupagem jurídica, já que ao mesmo tempo em que o estado de exceção foi proclamado por via constitucional como uma ditadura comissária, em sua proclamação e seu funcionamento, o Presidente do Reich se apresenta acima da lei como poder constituído consolidando na suspensão de direitos de maneira integral e não temporária, a despeito da própria Constituição, a expressão de uma ditadura soberana. (Cf. AGAMBEN, G. 2004, 91-92)
}

Mestre em Filosofia pela Universidade de São Paulo. Residente em São Paulo - SP. E-mail: michel.amary@gmail.com 
procurava na morte a expiação de sua culpa e transcendência, mas só encontrava a repetição do mesmo ciclo de violência história. Este era o paradigma histórico de gerações que se perpetuava teologizado em seu tempo; ao campo contrário cabia um conceito de história que levasse a transcendência política, e este certamente não passava pelo fascismo. Desse modo é que ao analisar o século XVII, Benjamin não apenas forneceu uma interpretação basilar sobre o seu próprio tempo, como uma original contribuição para pensarmos a contemporaneidade.

\section{REFERÊNCIAS}

ADORNO, T; BENJAMIN, W. Correspondências 1928-1940. São Paulo: Unesp, 2012.

ADORNO, T; HORKHEIMER, M. A dialética do esclarecimento. Rio de Janeiro: Zahar, 2006.

AGAMBEN, G. Estado de exceção. São Paulo: Boitempo, 2004.

BENJAMIN, W. A obra de arte na época da sua possibilidade de sua reprodução técnica ( $3^{\underline{a}}$ versão). In__: Estética e sociologia da arte. Belo Horizonte: Autêntica, 2017.

. In_ : Capitalismo como religião. São Paulo: Boitempo, 2014.

- "As armas do futuro" (a), "Capitalismo como religião" (b), "De cidadão do mundo a grão-burguês" (c) e "Drama barroco e Tragédia" (d).

. In_ : Documentos de cultura, documentos de barbárie:

escritos escolhidos. São Paulo: Cultrix, Edusp, 1986.

- "Experiência e pobreza" (a) e "Stefan George em retrospectiva" (b)

. Gesammelte Briefe. Band II. Frankfurt am Main: Suhrkamp,

1996.

. Origem do drama trágico alemão. Belo Horizonte, Autêntica,

2011.

Oficial: 2006.

. Passagens. Belo Horizonte e São Paulo, UFMG e Imprensa 
Autêntica, 2013.

. Rua de mão única e infância berlinese. Belo Horizonte:

- "Alarme contra incêndio", "Ministério Interior", "Panorama imperial", "Para o planetário" e "Posto de gasolina"

incêndio. São Paulo: Boitempo, 2005.

Sobre o conceito de história. In _ : Walter Benjamin: aviso de . Teoria do fascismo alemão. In_: Obras escolhidas: magia, técnica, arte e política. São Paulo: Brasiliense, 1996.

BERCOVICI, G. Constituição e estado de exceção permanente: a atualidade de Weimar. São Paulo: Azougue editorial, 2004.

BOLLE, W. Fisionomia da Metrópoles Moderna. São Paulo: Edusp, 2000.

Quarenta, 2014.

História: Conceptos de Walter Benjamin. Buenos Aires: Las

BUCK-MORSS, S. A dialética do olhar: Walter Benjamin e o projeto das

Passagens. Belo Horizonte: Editora UFMG, 2002.

DYMETMAN, A. Uma arquitetura da indiferença. São Paulo: Perspectiva, 2002.

ELIAS, N. O processo civilizador. Rio de Janeiro: Zahar Edições, 1994.

. Os alemães. Rio de Janeiro: Zahar Edições, 1992.

KLEIN, C. Weimar. São Paulo: Perspectiva, 1995.

MATOS, O. Modernidade: república em estado de exceção. In__: Revista USP. São Paulo, ํㅜ 59, 2003.

RICHARDS, L. A república de Weimar. São Paulo, Cia das Letras, 1988.

RINGER, F. O declínio dos mandarins alemães. São Paulo, Edusp, 2000.

ROUANET, S. Apresentação de Origem do drama barroco alemão. São Paulo: Brasiliense, 1984.

SCHOLEM, G. A história de uma amizade. São Paulo: Perspectiva, 1985.

TIEDEMANN, R; SCHWEPPENHÄUSER, H. Comentários. In_ : BENJAMIN. W. Origem do drama trágico alemão. Belo Horizonte, Autêntica, 2011.

WITTE, B. Walter Benjamin: uma biografia. Belo Horizonte: Autêntica, 2017. 